\title{
Benzo(a)pyrene-7,8-diol 9,10-Epoxide
}

National Cancer Institute

\section{Source}

National Cancer Institute. Benzo(a)pyrene-7,8-diol9,10-Epoxide. NCI Thesaurus. Code C196.

A polycyclic aromatic hydrocarbon and metabolite of benzo(a)pyrene with potent cytotoxic and mutagenic properties. Benzo(a)pyrene-7,8-diol-9,10-epoxide binds directly to DNA and disrupts DNA replication. 